\title{
Article \\ Kaempferol and Its Glycoside Derivatives as Modulators of Etoposide Activity in HL-60 Cells
}

\author{
Magdalena Kluska ${ }^{1}$, Michał Juszczak ${ }^{1}$, Jerzy Żuchowski ${ }^{2}$, Anna Stochmal ${ }^{2}{ }^{\circledR}$ and Katarzyna Woźniak ${ }^{1, *}$ (1) \\ 1 Department of Molecular Genetics, Faculty of Biology and Environmental Protection, University of Lodz, \\ 90-236 Lodz, Poland; magdalena.kluska@edu.uni.lodz.pl (M.K.); michal.juszczak@edu.uni.lodz.pl (M.J.) \\ 2 Department of Biochemistry and Crop Quality, Institute of Soil Science and Plant Cultivation, State Research \\ Institute, 24-100 Pulawy, Poland; jzuchowski@iung.pulawy.pl (J.Ż.); asf@iung.pulawy.pl (A.S.) \\ * Correspondence: katarzyna.wozniak@biol.uni.lodz.pl; Tel.: +48-42-635-47-76; Fax: +48-42-635-44-84
}

Citation: Kluska, M.; Juszczak, M.;

Żuchowski, J.; Stochmal, A.; Woźniak, K. Kaempferol and Its Glycoside Derivatives as Modulators of Etoposide Activity in HL-60 Cells. Int. J. Mol. Sci. 2021, 22, 3520. https:// doi.org/10.3390/ijms22073520

Academic Editor: Dimitrios Kouretas

Received: 25 February 2021

Accepted: 23 March 2021

Published: 29 March 2021

Publisher's Note: MDPI stays neutral with regard to jurisdictional claims in published maps and institutional affiliations.

Copyright: (c) 2021 by the authors. Licensee MDPI, Basel, Switzerland. This article is an open access article distributed under the terms and conditions of the Creative Commons Attribution (CC BY) license (https:/ / creativecommons.org/licenses/by/ $4.0 /)$.

\begin{abstract}
Kaempferol is a polyphenol found in a variety of plants. Kaempferol exerts antitumor properties by affecting proliferation and apoptosis of cancer cells. We investigated whether kaempferol and its glycoside derivatives-kaempferol 3-O-[(6-O-E-caffeoyl)- $\beta$-D-glucopyranosyl-(1 $\rightarrow 2)]-\beta-D-$ galactopyranoside-7-O- $\beta$-D-glucuropyranoside (P2), kaempferol 3-O-[(6-O-E-p-coumaroyl)- $\beta$-Dglucopyranosyl- $(1 \rightarrow 2)]-\beta$-D-galactopyranoside-7-O- $\beta$-D-glucuropyranoside (P5) and kaempferol 3O-[(6-O-E-feruloyl)- $\beta$-D-glucopyranosyl- $(1 \rightarrow 2)]-\beta$-D-galactopyranoside-7-O- $\beta$-D-glucuropyranoside (P7), isolated from aerial parts of Lens culinaris Medik.- -affect the antitumor activity of etoposide in human promyelocytic leukemia (HL-60) cells. We analyzed the effect of kaempferol and its derivatives on cytotoxicity, DNA damage, apoptosis, cell cycle progression and free radicals induced by etoposide. We demonstrated that kaempferol increases the sensitivity of HL-60 cells to etoposide but does not affect apoptosis induced by this drug. Kaempferol also reduces the level of free radicals generated by etoposide. Unlike kaempferol, some of its derivatives reduce the apoptosis of HL-60 cells (P2 and P7) and increase the level of free radicals (P2 and P5) induced by etoposide. Our results indicate that kaempferol and its glycoside derivatives can modulate the activity of etoposide in HL-60 cells and affect its antitumor efficacy in this way. Kaempferol derivatives may have the opposite effect on the action of etoposide in HL-60 cells compared to kaempferol.
\end{abstract}

Keywords: kaempferol; etoposide; DNA damage; apoptosis; cell cycle; oxidative stress; HL-60 cells

\section{Introduction}

Kaempferol [3,5,7-trihydroxy-2-(4-hydroxyphenyl)-4H-1-benzopyran-4-one] (Fig. 1A) is a flavonoid with an anticancer potential that can be found in a variety of plants and plant-derived food products, such as lentils, tea, broccoli or apples [1-4]. This flavonoid can modulate a number of key elements in cellular signal transduction pathways linked to apoptosis, angiogenesis, inflammation and metastasis [1]. Moreover, kaempferol, akin to other polyphenols, has strong antioxidant properties and can protect cells from oxidative stress. Oxidative stress plays a major role in the development of many diseases, including cancer. It is suggested that the anticancer properties of phenolic compounds such as kaempferol are in part due to their antioxidant properties. Both kaempferol and its glycoside derivatives show antioxidant activity by scavenging free radicals as well as inhibiting pro-oxidant enzymes and activating antioxidant enzymes [3]. Many studies have shown that polyphenols, including flavonoids, can sensitize cancer cells to anticancer drugs and radiotherapy, increasing their effectiveness $[5,6]$. The well-known examples in this respect are resveratrol [7,8], genistein [9], curcumin [10-12] and quercetin [13]. 

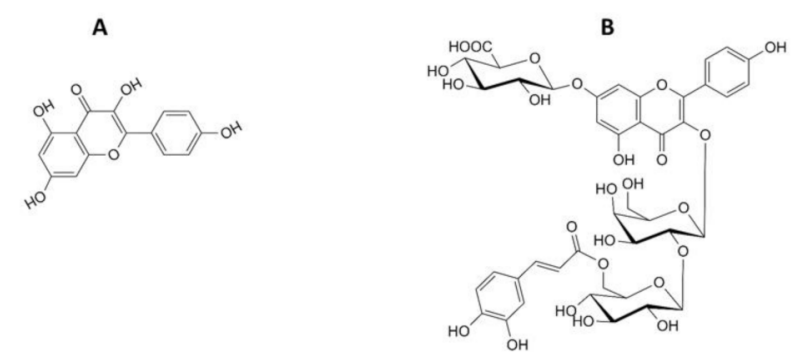

c

D
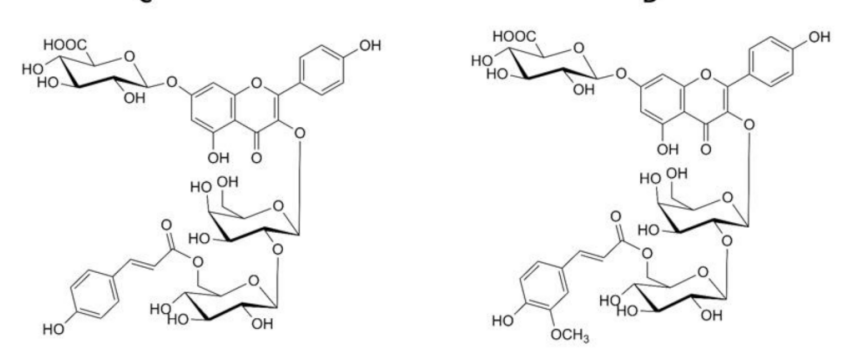

Figure 1. Chemical structures of kaempferol and its derivatives isolated from Lens culinaris Medik. (A) Kaempferol; (B) kaempferol 3-O-[(6-O-E-caffeoyl)- $\beta$-D-glucopyranosyl$(1 \rightarrow 2)$ ]- $\beta$-D-galactopyranoside-7-O- $\beta$-D-glucuropyranoside (P2); (C) kaempferol 3-O-[(6-O-E-pcoumaroyl)- $\beta$-D-glucopyranosyl- $(1 \rightarrow 2)]-\beta$-D-galactopyranoside-7-O- $\beta$-D-glucuropyranoside (P5); (D) kaempferol 3-O-[(6-O-E-feruloyl)- $\beta$-D-glucopyranosyl- $(1 \rightarrow 2)]-\beta-D-$ galactopyranoside-7-O- $\beta$-Dglucuropyranoside (P7).

Chemotherapeutic agents used in leukemia treatment include topoisomerase II inhibitors, such as doxorubicin and etoposide. Etoposide (epipodophyllotoxin) is a semisynthetic derivative of podophyllotoxin, a nonalkaloid lignan isolated from dried roots and rhizomes of Podophyllum peltatum or Podophyllum emodi (Berberidaceae) [14]. A primary target for etoposide is topoisomerase II. Etoposide destroys cells by stabilizing a covalent enzyme-cleaved DNA complex, which is a transient intermediate in the catalytic cycle of topoisomerase II. The accumulation of cleavage complexes in treated cells leads to the generation of permanent DNA strand breaks, which can trigger cell deaths. The efficiency of etoposide's cytostatic activity is dependent on the phase of the cell cycle, being the highest in the S phase [14]. Etoposide is also metabolized by cytochrome P450, horseradish peroxidase, and tyrosinase to an etoposide phenoxy radical, o-quinone-etoposide. The presence of the $4^{\prime}-\mathrm{OH}$ in etoposide has been found to be essential for the formation of the radical of this drug, its metabolites, as well as the antitumor activity [15]. Unfortunately, standard chemotherapy is nonspecific and affects both cancer and normal cells inducing a lot of side effects such as neutropenia, anemia, hair loss, and nausea. Therefore, we are looking for a compound which, on one hand, would enhance the effect of chemotherapeutic agents on cancer cells, and, on the other hand, protect normal cells. Such compounds may be the polyphenols. Recently, it has been demonstrated that kaempferol protected the vascular endothelium against doxorubicin-induced damage by regulating 14-3-3 $\gamma$ and ADMA/DDAHII/eNOS/NO pathways, inhibiting oxidative stress, and improving mitochondrial function [16]. Other polyphenols, such as curcumin [17] and quercetin [18], also protect cardiomyocytes against doxorubicin-induced toxicity by suppressing oxidative stress and preventing mitochondrial dysfunction mediated by 14-3$3 \gamma$. We have previously observed that kaempferol glycosides isolated from aerial parts of Lens culinaris Medik.--kaempferol-3-O-[(6-O-E-feruloyl)- $\beta$-D-glucopyranosyl- $(1 \rightarrow 2)]-\beta-D-$ galactopyranoside-7-O- $\beta$-D-glucuro-pyranoside, kaempferol-3-O- $\{[(6-\mathrm{O}-\mathrm{E}-\mathrm{p}$-coumaroyl)$\beta$-Dglucopyranosyl-( $(\rightarrow 2)]-\alpha$-L-rhamnopyranosyl $(1 \rightarrow 6)\}-\beta$-D-galactopyranoside-7-O- $\alpha$-Lrhamnopyranoside and kaempferol-3-O-[(6-O-E-caffeoyl)- $\beta$-D-glucopyranosyl- $(1 \rightarrow 2)]-\beta$ D-galactopyranoside-7-O-(2-O-E-caffeoyl')- $\beta$-D-glucuropyranoside-reduced DNA dam- 
age induced by etoposide in peripheral blood mononuclear cells (PBMCs), but did not have an impact on DNA damage in human promyelocytic leukemia (HL-60) cells [19].

Our earlier studies prompted us to the present examination of the effect of kaempferol and its glycoside derivatives (Figure 1) isolated from lentils on anticancer activity of etoposide in HL-60 cells. Here, we studied the effect of these plant compounds on cytotoxicity, apoptosis and reactive oxygen species (ROS) induced by etoposide. Furthermore, we tested the effect of kaempferol and its glycosides on DNA damage and cell cycle progression in HL-60 cells incubated with etoposide.

\section{Results and Discussion}

Different polyphenols, including kaempferol, have anticancer properties and can be used in cancer prevention and treatment. Flavonoids are found in plant material mainly in the form of glycosides [20]. Therefore, we decided to investigate the effects of not only kaempferol but also its glycoside derivatives isolated from aerial parts of Lens culinaris Medik. on the anticancer activity of etoposide in HL-60 cells. This is the first study that focuses on the effect of kaempferol and its glycosides on etoposide activity such as cytotoxicity, induction of apoptosis and DNA damage, cell cycle arrest and production of free radicals.

\subsection{Cytotoxicity}

We observed that etoposide decreased the viability of HL-60 cells after $24 \mathrm{~h}$ incubation at all three tested concentrations $(1,5$ and $10 \mu \mathrm{M})$ (Figure 2A). We also observed that coincubation of HL-60 cells with kaempferol and etoposide increased the cytotoxic effect of the drug notably. The incubation of HL-60 cells with $1 \mu \mathrm{M}$ etoposide and $50 \mu \mathrm{g} / \mathrm{mL}$ kaempferol was more cytotoxic ( $69 \%$ of cell viability) than the incubation with only etoposide $(83.2 \%)(p<0.001)$ (Figure 2A). Moreover, kaempferol with $5 \mu \mathrm{M}$ etoposide decreased cell viability from $58.2 \%$ to $50.6 \%$ and to $34 \%$ at 10 and $50 \mu \mathrm{g} / \mathrm{mL}$ concentrations, respectively $(p<0.001)$. In the case of $10 \mu \mathrm{M}$ etoposide, coincubation with kaempferol at 10 and $50 \mu \mathrm{g} / \mathrm{mL}$ concentrations decreased cell viability from $51.2 \%$ to $43.8 \%$ and to $30.8 \%$, respectively $(p<0.001)$. Next, we investigated the impact of kaempferol and its glycosides (P2, P5, P7), isolated from aerial parts of Lens culinaris Medik. on the cytotoxic effects of etoposide (Figure 2B,D). Kaempferol glycosides did not affect the cytotoxicity induced by etoposide in HL-60 cells. Only the P2 derivative decreased cell viability after incubation with $1 \mu \mathrm{M}$ etoposide from $85.2 \%$ to $79.8 \%(p<0.05)$ and $71.6 \%(p<0.001)$ at 10 and $50 \mu \mathrm{g} / \mathrm{mL}$ concentrations, respectively (Figure $2 \mathrm{~B}$ ).

Our research indicates that only kaempferol has the effect of increasing the cytotoxicity of etoposide in HL-60 cells. Its glycoside derivatives tested by us did not affect the cytotoxicity of etoposide, except the P2 derivative, which decreased the viability of HL60 cells incubated with $1 \mu \mathrm{M}$ etoposide. The results obtained by us are consistent with the previous results. Studies carried out on the colon cancer LS174 cell line compared the cytotoxic activity of kaempferol and its analogs-i.e., kaempferol 3-O-glucoside and kaempferol 3-O-rutinoside isolated from the Tunisian quince Cydonia oblonga Miller [21]. Kaempferol, at a concentration of $120 \mu \mathrm{M}$, induced more than $80 \%$ of growth inhibition after $72 \mathrm{~h}$ incubation, while this effect did not exceed $30 \%$ and $37 \%$ for kaempferol 3-O-glucoside and kaempferol 3-O-rutinoside, respectively. Based on in silico analysis, it was suggested that these differences in antitumor activity between kaempferol and its analogs were caused by the absence of glucosyl groups in a kaempferol molecule. Moreover, it was shown that kaempferol displayed the highest antiproliferation effect on the human hepatoma cell line HepG2 $\left(\mathrm{IC}_{50}=30.92 \mu \mathrm{M}\right)$, mouse colon cancer cell line CT26 $\left(\mathrm{IC}_{50}=88.02 \mu \mathrm{M}\right)$ and mouse melanoma cell line B16F1 $\left(\mathrm{IC}_{50}=70.67 \mu \mathrm{M}\right)$ compared to kaempferol-7-O-glucoside, kaempferol-3-O-rhamnoside and kaempferol-3-O-rutinoside $\left(\mathrm{IC}_{50}>100 \mu \mathrm{M}\right.$ after $24 \mathrm{~h}$ incubation) [22]. 

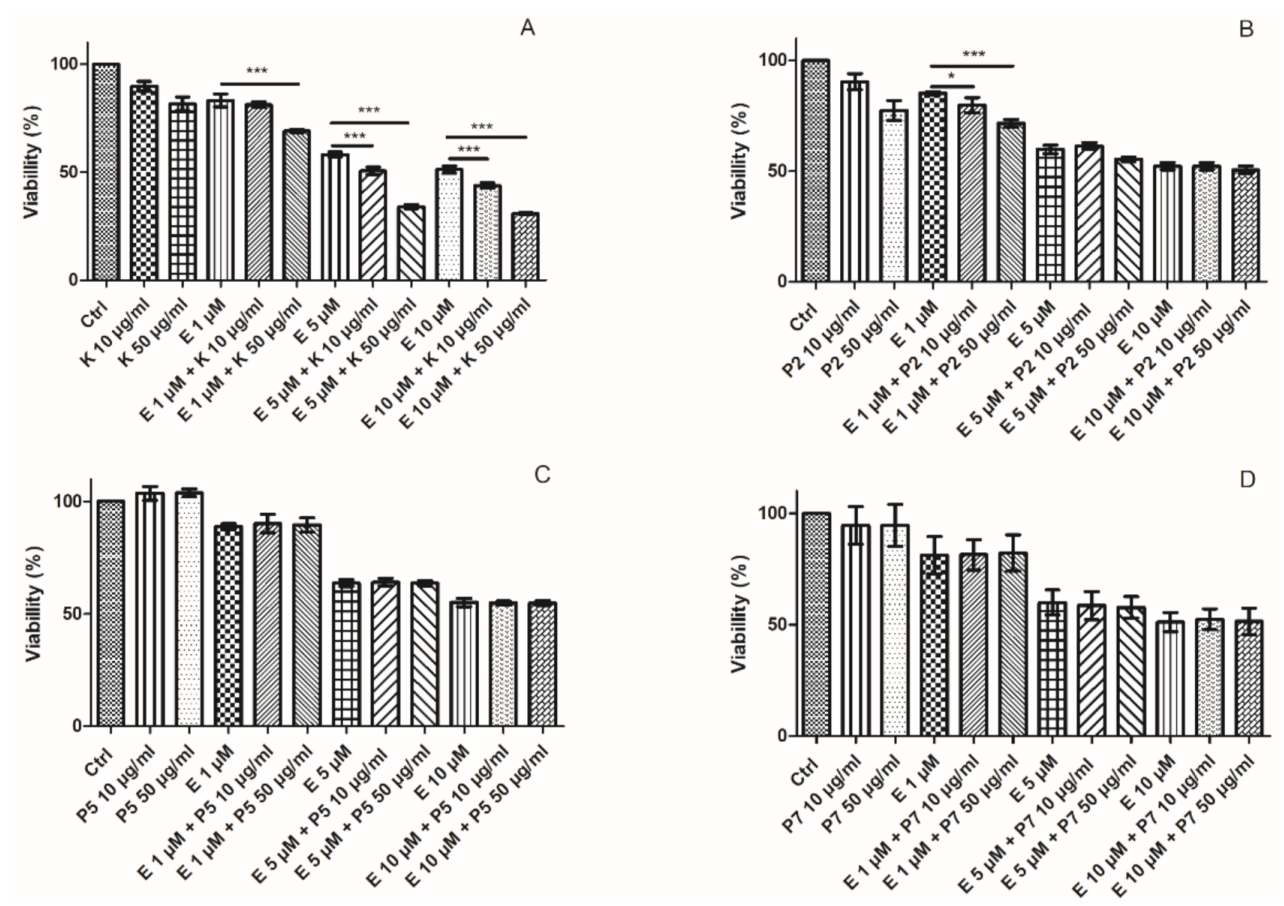

Figure 2. Viability of HL-60 cells determined by resazurin reduction assay after $24 \mathrm{~h}$ treatment with 1-10 $\mu \mathrm{M}$ etoposide (E) and 10-50 $\mu \mathrm{g} / \mathrm{mL}$ kaempferol (K) (A), P2 (B), P5 (C) and P7 (D) derivatives. The figure shows mean results $\pm \mathrm{SD}, n=6{ }^{*} p<0.05,{ }^{* * *} p<0.001$.

Additionally, we examined the effect of etoposide, kaempferol and its glycoside derivatives on the morphology of HL-60 cells using phase-contrast microscopy (Figure 3A,C). Firstly, we observed that $5 \mu \mathrm{M}$ etoposide decreased the number of HL-60 cells, with the cells becoming rough with shrinkage in comparison to the control cells. Moreover, the cells incubated with etoposide did not form clusters as control cells did (Figure 3A). Cells became enlarged and some of them had a fragmented nucleus. Similar changes in cell morphology were caused after incubation with $20 \mu \mathrm{M}$ camptothecin (CAM), the inhibitor of topoisomerase I. Kaempferol also changed the morphology of cells, making them rough and not clustering as control cells did. Coincubation with etoposide and kaempferol led to a reduction in the number of cells and did not change their morphology. These results are consistent with our examination of HL-60 cells viability (Figure 2). We observed that kaempferol derivatives did not change the morphology of HL-60 cells (Figure 3B). Moreover, we detected that kaempferol derivatives protected HL-60 cells against morphological changes induced by etoposide (Figure 3C). 


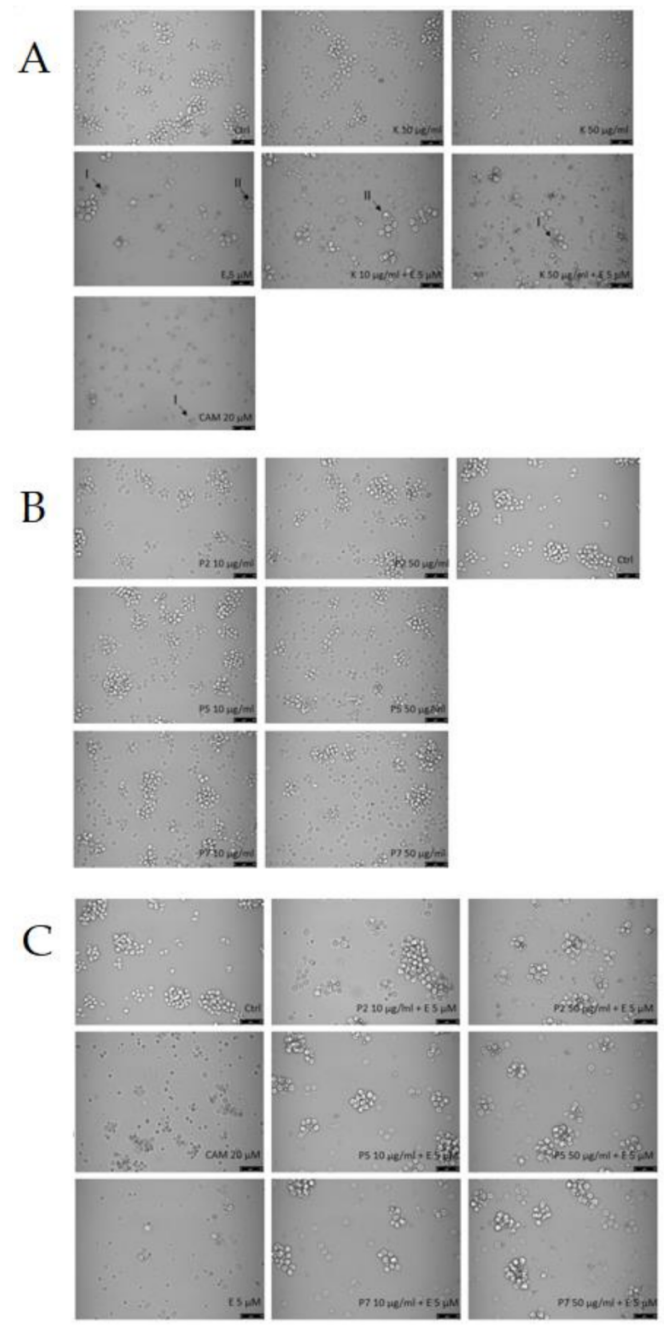

Figure 3. Morphological changes of human promyelocytic leukemia (HL-60) cells as examined by phase-contrast microscopy (magnification, $\times 200$ ) after incubation with kaempferol and etoposide (A), kaempferol derivatives (B) or kaempferol derivatives and etoposide (C). Cells with fragmented nuclei (I) and enlarged cells (II).

\subsection{DNA Damage}

Next, we tested the level of DNA damage following exposure to kaempferol derivatives and etoposide. Previously, we showed that kaempferol alone induced DNA damage in HL-60 cells as well as increased DNA damage induced by etoposide [19]. Coincubation of HL-60 cells with $1 \mu \mathrm{M}$ etoposide and $50 \mu \mathrm{g} / \mathrm{mL}$ kaempferol increased the level of DNA damage from $27.5 \%$ to $39.6 \%(p<0.001)$. Here, we did not observe any changes in the level of DNA damage induced by etoposide in HL-60 cells incubated with the two tested kaempferol derivatives (P2 and P5) (Figure 4). Figure 5 shows representative photos of the comets obtained after the incubation of HL-60 cells with these kaempferol derivatives $(10-50 \mu \mathrm{g} / \mathrm{mL})$ and $1 \mu \mathrm{M}$ etoposide. The data are consistent with our previous results for two other kaempferol derivatives isolated from Lens culinaris Medik. [19]. 

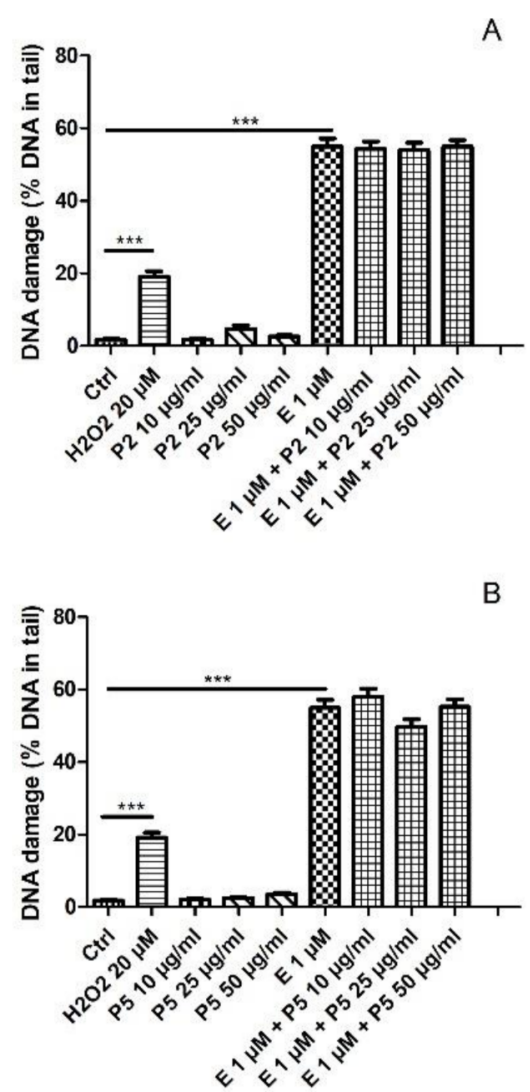

Figure 4. DNA damage, measured as the comet tail DNA (\%) of HL-60 cells incubated for $2 \mathrm{~h}$ at $37{ }^{\circ} \mathrm{C}$ with P2 (A) and P5 (B) derivative $(10-50 \mu \mathrm{g} / \mathrm{mL})$ and $1 \mu \mathrm{M}$ etoposide (E), analyzed by the alkaline comet assay. The figure shows mean results \pm standard error of the mean (SEM), $n=100$; *** $p<0.001$.
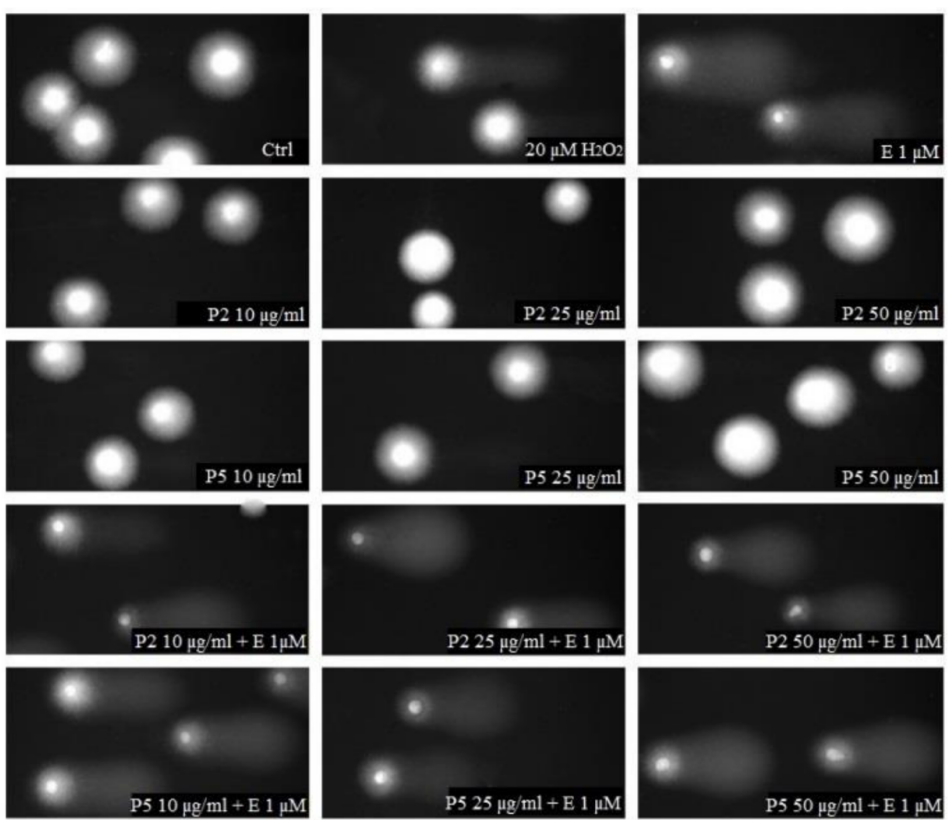

Figure 5. Representative pictures of comets obtained in the alkaline version of the comet assay after incubation of HL-60 cells with 10, 25 or $50 \mu \mathrm{g} / \mathrm{mL}$ P2 and P5 kaempferol derivatives and $1 \mu \mathrm{M}$ etoposide (E). The figure also contains pictures of comets from negative control (Ctrl) and positive control (cells incubated with $\mathrm{H}_{2} \mathrm{O}_{2}$ at $20 \mu \mathrm{M}$ for 15 min on ice). 
Kaempferol is a well-known compound that induces apoptosis of cancer cells, one of the manifestations of which is DNA fragmentation [23-25]. Wu et al. (2015) observed when using the comet assay that kaempferol induced DNA damage in a dose-dependent manner in HL-60 cells [24]. Recent studies have also shown that bioflavonoids, including kaempferol, induce DNA double strand breaks (DSBs) and $\gamma \mathrm{H} 2 \mathrm{AX}$ foci formation [26]. Moreover, Western blotting indicated that kaempferol-decreased protein expression was associated with the DNA repair system, such as phosphate-ataxia-telangiectasia mutated (p-ATM), phosphate-ataxia-telangiectasia and Rad3-related (p-ATR), 14-3-3 proteins sigma

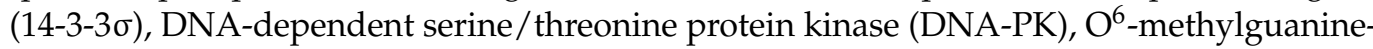
DNA methyltransferase (MGMT), p53 and MDC1 protein expressions [24]. In mammalian cells, the phosphorylation of the subtype of histone $\mathrm{H} 2 \mathrm{~A}$, called $\mathrm{H} 2 \mathrm{AX}$, in the position of Ser139 occurs in response to DSBs [27]. The phosphorylated form of H2AX is called $\gamma \mathrm{H} 2 \mathrm{AX}$. Histone H2AX is a substrate for several phosphoinositide 3-kinase-related protein kinases (PIKKs), such as ATM, ATR or DNA-PK. Phosphorylation of H2AX plays a key role in DNA damage response (DDR) and is required for the assembly of DNA repair proteins at the sites containing damaged chromatin as well as for activation of checkpoints proteins which arrest the cell cycle progression [27].

\subsection{Apoptosis}

To investigate whether a drop in the viability of HL-60 cells, which we observed during the coincubation with kaempferol and etoposide, was due to an increase in programmed cell death, we examined the level of apoptotic HL-60 cells after incubation $(24 \mathrm{~h})$ with $5 \mu \mathrm{M}$ etoposide, 10 and $50 \mu \mathrm{g} / \mathrm{mL}$ kaempferol, kaempferol derivatives (P2, P5, P7) and with combinations of these compounds. The cells incubated with $20 \mu \mathrm{M}$ camptothecin (CAM) were the positive control [28]. Our results indicate that kaempferol does not have an impact on the level of apoptosis induced by etoposide in HL-60 cells (Figure 6A). Hence, an increase in the cytotoxic effect of etoposide after coincubation with kaempferol is not associated with apoptosis. Studies carried out on HL-60 cells demonstrated that quercetin protected cells from apoptosis induced by etoposide [29]. However, quercetin at low concentrations $(5-30 \mu \mathrm{M})$ attenuated the therapeutic effects of cisplatin and other antineoplastic drugs in ovarian cancer cells by reducing ROS damage and increasing the expression of endogenous antioxidant enzymes, suggesting a ROS-mediated mechanism of attenuating anticancer drugs [30]. On the other hand, another polyphenol, curcumin, significantly enhanced apoptosis induced by etoposide in HL-60 cells [12].

Our result is somewhat surprising given that, as we have previously shown, kaempferol increased etoposide-induced DNA damage in HL-60 cells [19]. Moreover, kaempferol induces apoptosis of cancer cells which has been confirmed in numerous experiments. Moradzadeh et al. showed that kaempferol at the concentrations of 50 and $100 \mu \mathrm{M}$ decreased the viability of HL-60 cells after $72 \mathrm{~h}$ incubation [31]. Incubation with kaempferol for $72 \mathrm{~h}$ enhanced apoptosis in HL-60 cells via both intrinsic and extrinsic pathways. We did not observe apoptosis after $24 \mathrm{~h}$ incubation of HL-60 cells with kaempferol (10 and $50 \mu \mathrm{g} / \mathrm{mL}$ ) (Figure 6A). This is probably due to the shorter incubation time used by us compared to other studies [31]. However, we deliberately used a shorter incubation time with kaempferol to prevent cell apoptosis. In our opinion, only then can we evaluate the effect of kaempferol on etoposide-induced apoptosis. It was also shown that kaempferol decreased the viability and induced the apoptosis of HepG2 hepatocellular carcinoma cells [32]. Moreover, kaempferol also reduced the viability and increased the level of apoptosis in human cervical cancer (HeLa) cells [33]. These studies also showed that kaempferol had no toxic effect on normal human foreskin fibroblast (HFF) cells. Kaempferol derived from Semecarpus anacardium protected normal lung and liver cells from apoptosis induced by $\mathrm{H}_{2} \mathrm{O}_{2}$ [34]. This protective effect was associated with an increased expression of proteins responsible for the response to oxidative stress, such as Nrf2, superoxide dismutase (SOD), catalase and phospho-p38 MAPK. 

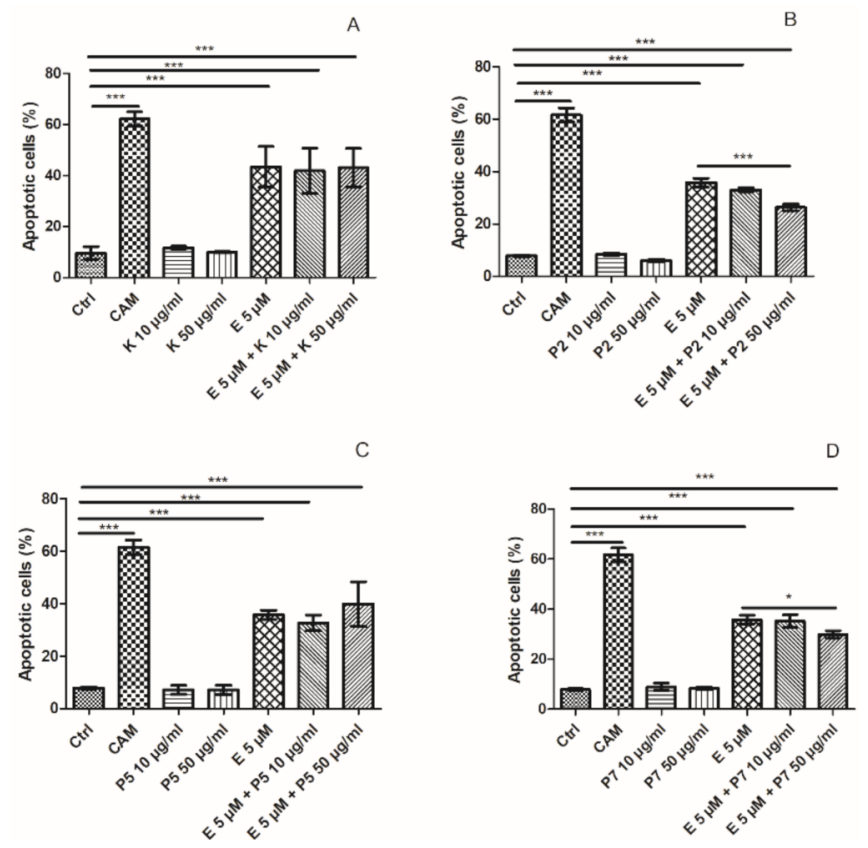

Figure 6. Apoptosis measured by flow cytometry using a double staining of FITC Annexin V and propidium iodide in HL-60 cells incubated for $24 \mathrm{~h}$ at $37{ }^{\circ} \mathrm{C}$ with $5 \mu \mathrm{M}$ etoposide (E) and 10 or $50 \mu \mathrm{g} / \mathrm{mL}$ kaempferol (K) (A), P2 (B), P5 (C) and P7 (D) derivatives. The cells incubated with $20 \mu \mathrm{M}$ camptothecin (CAM) for $24 \mathrm{~h}$ at $37^{\circ} \mathrm{C}$ were positive control. The figure shows mean results $\pm \mathrm{SD}$, $n=3 ;^{*} p<0.05,{ }^{* * *} p<0.001$.

We observed that all three tested kaempferol glycosides did not induce apoptosis in HL-60 cells by themselves (Figure 6B,D). Moreover, we noticed that the P2 derivative at the concentration of $50 \mu \mathrm{g} / \mathrm{mL}$ reduced the level of apoptosis induced by etoposide from $35.8 \%$ to $26.3 \%$ ( $p<0.001)$ (Figure 6B). Similarly, the P7 derivative decreased the level of apoptotic cells induced by etoposide from $35.8 \%$ to $29.8 \%(p<0.05)$ (Figure 6D). The opposite effect on apoptosis of leukemic cell lines U937, K562, and HL-60 cells was observed in the case of kaempferol-3-O-[ $\alpha$-1-rhamnopyranosyl-(1 $\rightarrow 4)-\mathrm{O}-\alpha-1-$ rhamnopyranosyl-( $(1 \rightarrow 6)-\mathrm{O}]-\beta-\mathrm{d}-$ glucopyranoside isolated from Wattakaka volubilis [35]. This glycoside derivative exhibited antileukemic activity with $\mathrm{IC}_{50}$ values of $13.5,10.8$, and $13.2 \mu \mathrm{g} / \mathrm{mL}$ in U937, $\mathrm{K} 562$, and HL-60 cell lines, respectively. The flow-cytometric analysis confirmed that the cell cycle arrest occurred at G1 phase in the case of U937 and K562 cell lines and G2/M phase in the case of HL-60 cell lines. Moreover, both confocal microscopic analysis and DNA laddering assay confirmed the apoptosis and cell cycle arrests of leukemic cells [35].

Summarizing our results on the effect of kaempferol and its derivatives on etoposideinduced apoptosis, it should be stated that kaempferol, in addition to strong proapoptotic properties, also exhibits strong antioxidant properties that can protect cancer cells against apoptosis. Our results indicate that glycoside derivatives of kaempferol, such as the compounds $\mathrm{P} 2$ and P7, which we analyzed, may have stronger antiapoptotic properties than kaempferol.

\subsection{Cell Cycle}

Next, we investigated the cell cycle progression in HL-60 cells after $24 \mathrm{~h}$ incubation with etoposide, kaempferol and its glycoside derivatives (Table 1). We observed that both kaempferol and its glycoside derivatives did not alter the progression of cell cycle. We also observed an increase in cell level in sub-G1 phase from $1.1 \%$ to $10.5 \%$ after incubation with $0.5 \mu \mathrm{M}$ etoposide $(p<0.01)$. Moreover, the G0/G1 fraction decreased significantly in response to $0.5 \mu \mathrm{M}$ etoposide compared to the control cells from $42.4 \%$ to $20 \%(p<0.001)$. The presence of cells in the sub-G1 phase is associated with apoptosis and DNA fragmentation. This result confirms the strong apoptotic effect of etoposide, as also shown in the 
experiment with double staining of cells with annexin $\mathrm{V}$ and propidium iodide (Figure 6). Our results are in agreement with the data obtained by Żuryn and colleagues on HL-60 cells treated with $0.5-1 \mu \mathrm{M}$ etoposide [36]. We also observed a slight decrease in the number of $\mathrm{S}$ phase cells after incubation with etoposide $(p<0.05)$. Additionally, etoposide increased the population of cells in G2/M phase from $24.4 \%$ to $50.2 \%(p<0.001)$. We noticed that both kaempferol and its glycoside derivatives had no impact on progression of cell cycle in cells incubated with etoposide (Table 1).

Table 1. Cell cycle distribution measured by flow cytometry using a staining with propidium iodide in HL-60 cells incubated for $24 \mathrm{~h}$ at $37^{\circ} \mathrm{C}$ with $0.5 \mu \mathrm{M}$ etoposide (E) and 10 or $50 \mu \mathrm{g} / \mathrm{mL}$ kaempferol (K), P2, P5 and P7 derivatives. The cells incubated with $100 \mathrm{ng} / \mathrm{mL}$ nocodazole (NOC) for $24 \mathrm{~h}$ at $37^{\circ} \mathrm{C}$ were positive control.

\begin{tabular}{|c|c|c|c|c|}
\hline \multirow{2}{*}{ Treatment/Concentration } & \multicolumn{4}{|c|}{ DNA Content (\%) } \\
\hline & sub-G1 & G0/G1 & $S$ & G2/M \\
\hline Ctrl & $1.1 \pm 0.6$ & $42.4 \pm 3.4$ & $32.1 \pm 1.2$ & $24.4 \pm 1.9$ \\
\hline NOC & $23.8 \pm 1.3^{* * *}$ & $33.7 \pm 9.6$ & $13.8 \pm 5.7^{* * *}$ & $28.7 \pm 7.1$ \\
\hline $\mathrm{K} 10 \mu \mathrm{g} / \mathrm{ml}$ & $1.2 \pm 0.6$ & $42.5 \pm 3.0$ & $29.0 \pm 3.0$ & $27.4 \pm 1.1$ \\
\hline $\mathrm{K} 50 \mu \mathrm{g} / \mathrm{ml}$ & $1.5 \pm 1.0$ & $33.7 \pm 5.7$ & $36.4 \pm 7.3$ & $28.4 \pm 3.1$ \\
\hline P $210 \mu \mathrm{g} / \mathrm{ml}$ & $1.1 \pm 0.9$ & $40.6 \pm 6.5$ & $31.6 \pm 6.0$ & $26.7 \pm 1.7$ \\
\hline $\mathrm{P} 250 \mu \mathrm{g} / \mathrm{ml}$ & $1.1 \pm 0.4$ & $44.0 \pm 4.1$ & $28.7 \pm 2.9$ & $26.2 \pm 1.8$ \\
\hline P $510 \mu \mathrm{g} / \mathrm{ml}$ & $1.0 \pm 0.9$ & $43.9 \pm 1.8$ & $27.8 \pm 1.8$ & $27.3 \pm 2.6$ \\
\hline P $550 \mu \mathrm{g} / \mathrm{ml}$ & $1.2 \pm 0.9$ & $43.0 \pm 5.8$ & $32.3 \pm 5.5$ & $23.5 \pm 0.5$ \\
\hline P $710 \mu \mathrm{g} / \mathrm{ml}$ & $1.1 \pm 0.8$ & $43.7 \pm 6.4$ & $30.2 \pm 5.4$ & $25.0 \pm 1.6$ \\
\hline P $750 \mu \mathrm{g} / \mathrm{ml}$ & $1.2 \pm 0.4$ & $46.8 \pm 2.2$ & $28.6 \pm 1.9$ & $23.4 \pm 0.5$ \\
\hline E $0.5 \mu \mathrm{M}$ & $10.5 \pm 6.0^{* *}$ & $20.0 \pm 2.6^{* * *}$ & $19.3 \pm 2.6^{*}$ & $50.2 \pm 6.0^{* * *}$ \\
\hline E $0.5 \mu \mathrm{M}+\mathrm{K} 50 \mu \mathrm{g} / \mathrm{ml}$ & $11.0 \pm 4.2^{* *}$ & $14.5 \pm 1.3^{* * *}$ & $18.4 \pm 0.6^{*}$ & $56.1 \pm 5.6^{* * *}$ \\
\hline E $0.5 \mu \mathrm{M}+\mathrm{P} 250 \mu \mathrm{g} / \mathrm{ml}$ & $9.4 \pm 3.1 *$ & $14.3 \pm 2.3^{* * *}$ & $16.5 \pm 2.2^{* *}$ & $59.8 \pm 5.7^{* * *}$ \\
\hline E $0.5 \mu \mathrm{M}+\mathrm{P} 550 \mu \mathrm{g} / \mathrm{ml}$ & $11.2 \pm 4.0^{* *}$ & $18.2 \pm 4.5^{* * *}$ & $17.0 \pm 1.0^{* *}$ & $53.5 \pm 7.4^{* * *}$ \\
\hline E $0.5 \mu \mathrm{M}+$ P $750 \mu \mathrm{g} / \mathrm{ml}$ & $12.6 \pm 3.0^{* * *}$ & $20.5 \pm 3.7^{* * *}$ & $17.0 \pm 2.7^{* *}$ & $50.0 \pm 4.3^{* * * *}$ \\
\hline
\end{tabular}

The table shows mean results $\pm \mathrm{SD} ; n=3 ;^{*} p<0.05,{ }^{* *} p<0.01,{ }^{* * *} p<0.001$.

Results of transcriptomic analysis supported by real-time qRT-PCR, obtained with the human fibroblast model, indicate that polyphenols, including kaempferol, may regulate cell cycle and DNA replication in human cells due to modulation of expression of a relatively large group of genes whose products are involved in these processes [37]. For example, it was demonstrated that kaempferol induced G2/M cell cycle arrest via the Chk2/Cdc25C/Cdc2 pathway and Chk2/p21/Cdc2 pathway in human ovarian cancer A2780/CP70 cells [38]. Kaempferol-mediated antitumor activity toward Jurkat T cells was attributable to G2-checkpoint activation, which not only caused G2-arrest of the cell cycle, but also the phosphorylation of p53 (Ser-15) and subsequent induction of mitochondriadependent apoptotic events [39].

Certain bioflavonoids such as kaempferol, quercetin and myricetin have been shown to directly inhibit topoisomerase II, similarly to etoposide [40]. Recent studies have shown that myricetin, genistein, and quercetin act most similarly to etoposide, although with varying topoisomerase II dependence. By contrast, kaempferol and luteolin have distinct kinetics that are mostly topoisomerase II-independent [26]. However, it should be emphasized that bioflavonoids can have a pleiotropic effect. Along with the ability to poison topoisomerase II, bioflavonoids can impact DNA repair processes, alter epigenetic markers, and activate signal transduction pathways, leading to altered protein expression in multiple pathways, such as cell cycle regulation, cell survival and cytokine expression [26,37]. The ability 
to inhibit topoisomerase II by substances of plant origins may lead to their antagonistic activity with etoposide in cancer cells [41].

\subsection{Free Radicals}

Firstly, we observed that $5 \mu \mathrm{M}$ etoposide induced the statistically significant increase in the level of intracellular ROS $(p<0.001)$ (Figures 7 and 8$)$. This confirms that etoposide at this concentration induces oxidative stress in HL-60 cells. Next, we investigated the induction of intracellular ROS in the cells treated with 10 and50 $\mathrm{gg} / \mathrm{mL}$ kaempferol or its glycoside derivatives (P2, P5, P7) and in combination with $5 \mu \mathrm{M}$ etoposide. We observed that $50 \mu \mathrm{g} / \mathrm{mL}$ kaempferol decreased the level of intracellular ROS in HL-60 cells $(p<0.001)$ compared to the control cells, which indicates that kaempferol reduces endogenous free radicals (Figure 7A). Moreover, $50 \mu \mathrm{g} / \mathrm{mL}$ kaempferol decreased the level of ROS induced by $5 \mu \mathrm{M}$ etoposide $(p<0.001)$ (Figures $7 \mathrm{~A}$ and 8$)$. We did not observe any changes in ROS induction by etoposide in the case of $10 \mu \mathrm{g} / \mathrm{mL}$ kaempferol. The presented results showed that the enhancement of etoposide cytotoxicity by kaempferol was not due an increase in ROS generation. The antioxidant activity of kaempferol does not limit the activity of the drug. Our results confirm the previous studies which demonstrated the antioxidant properties of kaempferol [21,22,34]. Not only is kaempferol a potent scavenger of superoxide anion, hydroxyl radical and peroxynitrite, but it also inhibits pro-oxidant enzymes, such as xanthine oxidase, and activates antioxidant enzymes such as superoxide dismutase, catalase and heme oxygenase- 1 , and even prevents the generation of hydroxyl radicals by chelating cuprous or ferrous. Moreover, kaempferol contains hydroxyl groups at $\mathrm{C} 3, \mathrm{C} 5$, and $\mathrm{C} 4$, an oxo group at $\mathrm{C} 4$, and a double bond at $\mathrm{C} 2-\mathrm{C} 3$ that might explain its antioxidant activity [3]. Kaempferol can control the cancer through its antioxidative/antinitrosative potential by restoring cell redox hemostasis by inhibiting the NF- $\mathrm{kB}$ pathway and upregulating the Nrf2 transcriptional pathway $[3,34]$.
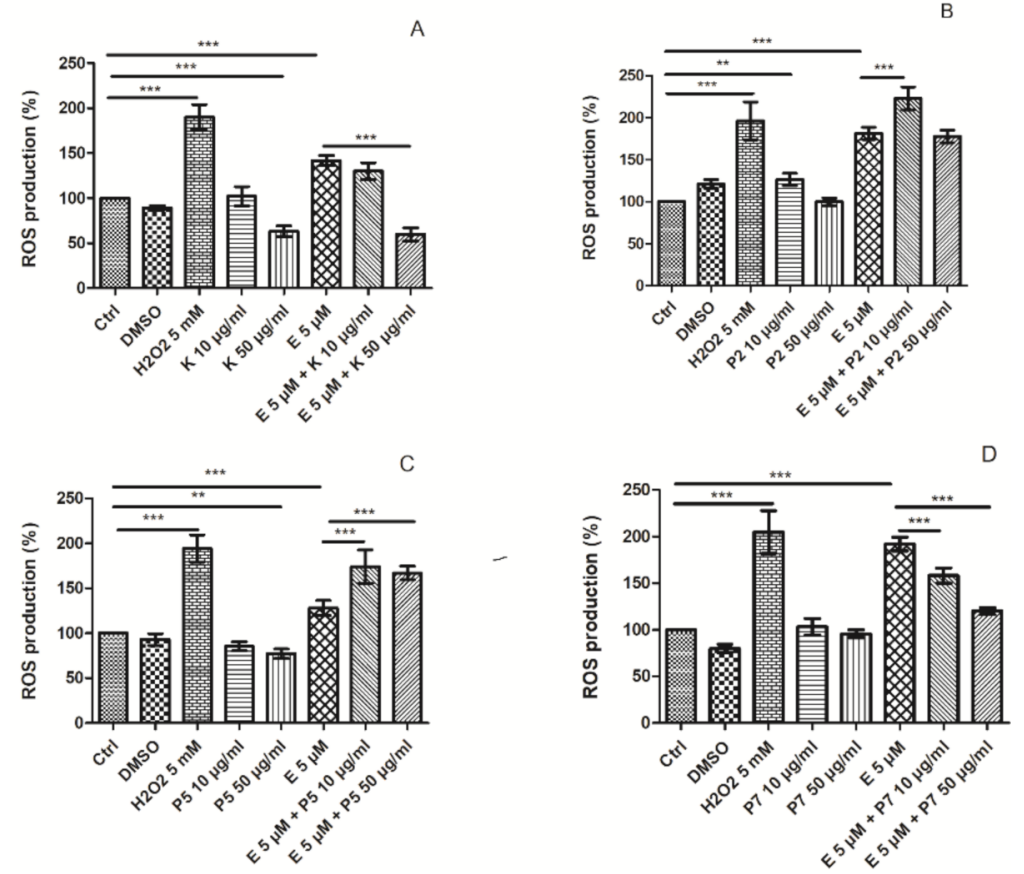

Figure 7. Reactive oxygen species (ROS) level in HL-60 cells incubated for $24 \mathrm{~h}$ at $37^{\circ} \mathrm{C}$ with $5 \mu \mathrm{M}$ etoposide (E) and $10 \mu \mathrm{g} / \mathrm{mL}$ or $50 \mu \mathrm{g} / \mathrm{mL}$ kaempferol (K) (A), P2 (B), P5 (C) and P7 (D) derivatives. The cells incubated with $5 \mathrm{mM} \mathrm{H}_{2} \mathrm{O}_{2}$ for $15 \mathrm{~min}$ at $37^{\circ} \mathrm{C}$ were positive control. The figure shows mean results $\pm \mathrm{SD}, n=6$; ** $p<0.01,{ }^{* * *} p<0.001$. 

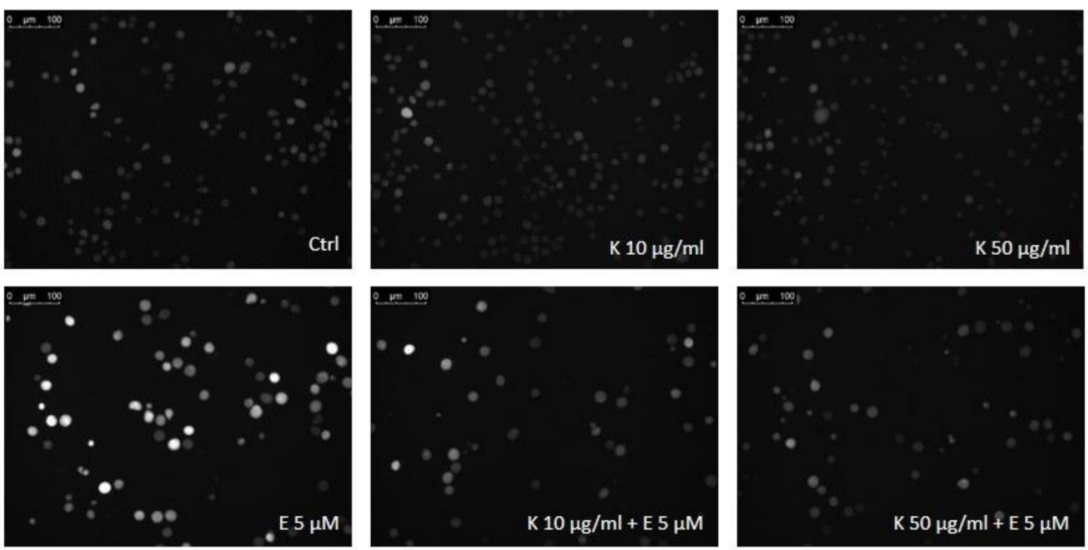

Figure 8. Representative photos of cells with 20 the fluorescence probe $\mathrm{H}_{2}$ DCFH-DA after $24 \mathrm{~h}$ incubation at $37^{\circ} \mathrm{C}$ with $5 \mu \mathrm{M}$ etoposide (E) and $10 \mu \mathrm{g} / \mathrm{mL}$ or $50 \mu \mathrm{g} / \mathrm{mL}$ kaempferol (K). The figure also contains pictures of comets from negative control (Ctrl).

Interestingly, we observed that the P2 derivative increased the level of intracellular ROS at the concentration of $10 \mu \mathrm{g} / \mathrm{mL}$ compared to the control cells $(p<0.01)$ (Figure 7B). Moreover, coincubation of $5 \mu \mathrm{M}$ etoposide with $10 \mu \mathrm{g} / \mathrm{mL} \mathrm{P2}$ and P5 at 10 and $50 \mu \mathrm{g} / \mathrm{mL}$ elevated the ROS level in comparison to the incubation with etoposide only $(p<0.001)$ (Figure 7B,C). However, this growth in ROS generation did not increase the cytotoxicity of etoposide. Our results suggest that the glycoside derivatives of kaempferol may act differently compared to kaempferol. On the other hand, P5 at the concentration of $50 \mu \mathrm{g} / \mathrm{mL}$ decreased the ROS level to 77\% compared to the control $(p<0.01)$ (Figure 7C). In contrast to P2 and P5, and similarly to kaempferol, the P7 derivative significantly decreased the level of ROS induced by etoposide $(p<0.001)$ (Figure 7D).

It was proposed that the synergistic enhancement of activity of anticancer drugs was caused by polyphenols: quercetin, apigenin, emodin, rhein and cis-stilbene are associated with the ability to change the glutathione (GSH) level in leukemic cells [42]. In the two lymphoid cell lines, CCRF-CEM and Jurkat, it was shown that all studied polyphenols when used in combination with topoisomerase II inhibitor, etoposide or doxorubicin, caused a synergistic or additive decrease in cell proliferation, $\mathrm{G}_{2} \mathrm{M}$ or $\mathrm{S}$ phase cell cycle arrest and apoptosis. This was associated with a synergistic/additive reduction in GSH levels, increased activity of caspases 3, 8 and 9 and DNA damage. Similar effects were observed in the myeloid cell lines, THP-1 and KG1a, when quercetin and apigenin were used in combination with topoisomerase II inhibitor. However, when emodin, rhein and to a lesser extent $c$ sis-stilbene were used in combination with etoposide or doxorubicin, there was an antagonistic increase in ATP, an inhibition of apoptosis and no cell cycle arrest. This was associated with an elevation of GSH levels and reduction in activity of caspases 3,8 and 9, and little or no DNA damage [42].

\section{Materials and Methods}

\subsection{Reagents}

3,4',5,7-Tetrahydroxyflavone (kaempferol) (K0133), 4'-demethylepipodophyllotoxin 9(4,6-O-ethylidene- $\beta$-D-glucopyranoside) (etoposide) (E1383), low-melting-point (LMP) and normal-melting-point (NMP) agarose, $4^{\prime}, 6$-diamidino-2-phenylindole (DAPI), dimethyl sulfoxide (DMSO), camptothecin (C9911), nocodazole (M1404), 2' ,7'-dichlorofluorescein diacetate $\left(\mathrm{H}_{2} \mathrm{DCFDA}\right)$, resazurin sodium salt (R7017) and hydrogen peroxide $\left(\mathrm{H}_{2} \mathrm{O}_{2}\right)$ were purchased from Sigma-Aldrich (St. Louis, MO, USA). Kaempferol was dissolved in DMSO and stored at $-20{ }^{\circ} \mathrm{C}$. Etoposide was dissolved in methanol. 


\subsection{Kaempferol Glycosides from the Aerial Parts of Lentil}

Kaempferol glycosides: kaempferol 3-O-[(6-O-E-caffeoyl)- $\beta$-D-glucopyranosyl-( $1 \rightarrow 2)]$ $\beta$-D-galactopyranoside-7-O- $\beta$-D-glucuropyranoside (P2), kaempferol 3-O-[(6-O-E-pcoumaroyl)- $\beta$-D-glucopyranosyl-( $1 \rightarrow 2)]-\beta$-D-galactopyranoside-7-O- $\beta$-D-glucuropyranoside (P5) and kaempferol 3-O-[(6-O-E-feruloyl)- $\beta$-D-glucopyranosyl-(1 $\rightarrow 2)]-\beta$-D-galactopyranoside-7-O- $\beta$-D-glucuropyranoside (P7) were isolated from aerial parts of Lens culinaris Medik. according to the procedure described by Żuchowski et al. (2014) [43]. All isolated kaempferol glycosides were dissolved in $50 \%$ DMSO and stored at $-20^{\circ} \mathrm{C}$.

\subsection{Cell Preparation}

The human promyelocytic leukemia (HL-60) cell line was obtained from the American Type Culture Collection (ATCC). The cells were cultured in flasks at $37{ }^{\circ} \mathrm{C}$ in $5 \% \mathrm{CO}_{2}$ atmosphere in Iscove's Modified Dulbecco's Medium (IMDM) with $2 \mathrm{mM}$ L-glutamine, $25 \mathrm{mM}$ HEPES (Lonza, Basel, Switzerland), 15\% inactivated fetal bovine serum (FBS) and penicillin/streptomycin solution (100 U/mL and $100 \mu \mathrm{g} / \mathrm{mL}$, respectively).

\subsection{Cell Treatment}

In all experiments, the HL-60 cells were seeded in the culture medium and then incubated at $37^{\circ} \mathrm{C}$ with different concentrations (10-50 $\left.\mu \mathrm{g} / \mathrm{mL}\right)$ of kaempferol and kaempferol derivatives: (P2), (P5) and (P7). The cells were also treated with different concentrations of etoposide $(1$ or $5 \mu \mathrm{M})$ and incubated for $2 \mathrm{~h}$ at $37^{\circ} \mathrm{C}$ until DNA damage induction or for $24 \mathrm{~h}$ at $37^{\circ} \mathrm{C}$ to measure viability, apoptosis, cell cycle, ROS induction and gene expression. The final concentration of DMSO and methanol in the samples did not exceed $0.5 \%$ [19].

\subsection{Cell Viability}

Cell viability was measured using the resazurin reduction assay based on the ability of viable cells to reduce resazurin to fluorescent resorufin. The HL-60 cells were seeded on 96-well plates at a density of $1 \times 10^{4}$ cells $/ \mathrm{mL}$ in a culture medium and incubated for $24 \mathrm{~h}$ with the tested compounds (etoposide, kaempferol, P2, P5, P7) at $37^{\circ} \mathrm{C}$ in $5 \% \mathrm{CO}_{2}$. The assay was described in detail by Juszczak et al. (2020) [44].

\subsection{DNA Damage}

DNA damage was estimated using the alkaline comet assay according to the procedure defined by Singh et al. (1988) [45], which was described in detail in the authors' previous work [19].

\subsection{Apoptosis}

Apoptosis was measured using the FITC Annexin V Apoptosis Detection Kit II (BD Biosciences, San Jose, USA). The HL-60 cells were seeded in 6-well plates at density of $2 \times 10^{5}$ cells $/ \mathrm{mL}$. The cells incubated with $20 \mu \mathrm{M}$ camptothecin (CAM) for $24 \mathrm{~h}$ at $37^{\circ} \mathrm{C}$ were the positive control. After incubation, the cells were collected and washed twice with ice-cold PBS. The cells were resuspended in $1 \times$ Binding Buffer $(100 \mu \mathrm{L})$ and incubated with FITC Annexin V $(5 \mu \mathrm{L})$ and propidium iodide (PI) $(5 \mu \mathrm{L})$ for $15 \mathrm{~min}$ at room temperature in the dark. Then, $400 \mu \mathrm{L}$ of Binding Buffer was added to each tube and the samples were measured within $1 \mathrm{~h}$ using the LSRII flow cytometer (Becton Dickinson, San Jose, leCA, USA) equipped with $488 \mathrm{~nm}$ laser excitation and BD FACSDiva software $\mathrm{v}$ 4.1.2. The percentage of apoptotic cells was expressed as a population of FITC Annexin V-positive cells [28].

\subsection{Cell Cycle}

The HL-60 cells were seeded in 6-well plates at density of $0.5 \times 10^{6}$ cells $/ \mathrm{mL}$ and incubated with the tested compounds. The cells incubated with $100 \mathrm{ng} / \mathrm{mL}$ nocodazol (NOC) for $24 \mathrm{~h}$ at $37^{\circ} \mathrm{C}$ were the positive control. Next, the cells were collected and washed twice with PBS. Then, the cells were resuspended in PBS and allowed to cool for $15 \mathrm{~min}$ on 
ice. Then, one volume of $-20^{\circ} \mathrm{C}$ absolute ethanol was added, and the samples were stored at $4{ }^{\circ} \mathrm{C}$. Before the analysis, samples were pelleted and resuspended in $300 \mu \mathrm{L}$ of staining solution containing $40 \mu \mathrm{g} / \mathrm{mL}$ PI and $200 \mu \mathrm{g} / \mathrm{mL}$ RNase A. Samples were incubated for $30 \mathrm{~min}$ at $37^{\circ} \mathrm{C}$ in the dark until analysis. DNA content was analyzed using the LSRII flow cytometer (Becton Dickinson, San Jose, CA, USA) [28].

\subsection{Detection of Reactive Oxygen Species}

The production of intracellular reactive oxygen species (ROS) was determined by measuring the fluorescence of $2^{\prime}, 7^{\prime}$-dichlorofluorescein diacetate $\left(\mathrm{H}_{2} \mathrm{DCFDA}\right)$. The cells (final density of $5 \times 10^{5}$ cells $/ \mathrm{mL}$ ) were seeded in 6-well plates and incubated with $5 \mu \mathrm{M}$ etoposide and 10 or $50 \mu \mathrm{g} / \mathrm{mL}$ kaempferol, P2, P5 and P7 derivatives for $24 \mathrm{~h}$ at $37^{\circ} \mathrm{C}$. The cells incubated for $15 \mathrm{~min}$ with $5 \mathrm{mM} \mathrm{H} \mathrm{O}_{2}$ at $37^{\circ} \mathrm{C}$ were the positive control. The assay was described in detail by Juszczak et al. (2020) [44].

\subsection{Statistical Analysis}

The values of the comet assay were expressed as mean + standard error of the mean (SEM) from two experiments; data from the experiments were pooled and statistical parameters were calculated. The data from cell viability, apoptosis detection, cell cycle distribution and ROS measurement are presented as mean values \pm SD from 3-6 independent experiments. Statistical analyses were performed using GraphPad Prism 5 (GraphPad Software Inc., La Jolla, CA, USA). Statistical differences were determined by means of a one-way ANOVA analysis followed by post hoc Tukey's multiple comparison test. The differences were considered to be statistically significant when the $p$ value was less than 0.05 .

\section{Conclusions}

Our results suggest that kaempferol is a rather weak modulator of etoposide activity in HL-60 cells. Perhaps this is due to the compensation of the effects of kaempferol, its derivatives and etoposide. Kaempferol increases the sensitivity of HL-60 cells to etoposide but does not increase apoptosis and ROS level induced by etoposide. Our study also shows that glycoside kaempferol derivatives, isolated from Lens culinaris Medik., can limit the apoptotic activity of etoposide in cancer HL-60 cells. However, the results presented here concern HL-60 cells only, which is a major limitation of our work. It would be interesting to assess how kaempferol and its glycoside derivatives affect the activity of etoposide in other cancer cells.

It seems that kaempferol and its glycoside derivatives may act similarly to emodin, rhein and cis-stilbene in combination with etoposide [42]. It cannot be ruled out that kaempferol and its derivatives, due to their strong antioxidant properties, will exert an antagonistic effect on the effect of etoposide action. Moreover, it is worth emphasizing that some of kaempferol derivatives may act differently than kaempferol. Our results indicate the need for further and more detailed research into the interactions between polyphenols, such as kaempferol and its derivatives, and chemotherapeutic agents used in the treatment of cancer.

Author Contributions: Conceptualization, K.W.; methodology, M.K., M.J. and J.Ż.; validation, M.K.; investigation, M.K. and M.J.; data curation, K.W.; writing—original draft preparation, M.K.; writingreview and editing, K.W.; visualization, M.K.; supervision, J.Ż., A.S. and K.W. All authors have read and agreed to the published version of the manuscript.

Funding: This research received no external funding.

Institutional Review Board Statement: Not applicable.

Informed Consent Statement: Not applicable.

Acknowledgments: This work was supported financially by the University of Lodz, Poland, the Faculty of Biology and Environmental Protection.

Conflicts of Interest: The authors declare no conflict of interest. 


\section{References}

1. Chen, A.Y.; Chen, Y.C. A review of the dietary flavonoid, kaempferol on human health and cancer chemoprevention. Food Chem. 2013, 138, 2099-2107. [CrossRef]

2. Zhou, Y.; Zheng, J.; Li, Y.; Xu, D.P.; Li, S.; Chen, Y.M.; Li, H.B. Natural Polyphenols for Prevention and Treatment of Cancer. Nutrients 2016, 8, 515. [CrossRef]

3. Imran, M.; Salehi, B.; Sharifi-Rad, J.; Aslam Gondal, T.; Saeed, F.; Imran, A.; Shahbaz, M.; Tsouh Fokou, P.V.; Umair Arsha, M.; Khan, H.; et al. Kaempferol: A Key Emphasis to Its Anticancer Potential. Molecules 2019, 24, 2277. [CrossRef] [PubMed]

4. Montané, X.; Kowalczyk, O.; Reig-Vano, B.; Bajek, A.; Roszkowski, K.; Tomczyk, R.; Pawliszak, W.; Giamberini, M.; MocekPłóciniak, A.; Tylkowski, B. Current Perspectives of the Applications of Polyphenols and Flavonoids in Cancer Therapy. Molecules 2020, 25, 3342. [CrossRef] [PubMed]

5. Lewandowska, U.; Gorlach, S.; Owczarek, K.; Hrabec, E.; Szewczyk, K. Synergistic Interactions Between Anticancer Chemotherapeutics and Phenolic Compounds and Anticancer Synergy Between Polyphenols. Postepy Hig. Med. Dosw. 2014, 68, 528-540. [CrossRef]

6. De Oliveira Júnior, R.G.; Christiane Adrielly, A.F.; da Silva Almeida, J.R.G.; Grougnet, R.; Thiéry, V.; Picot, L. Sensitization of tumor cells to chemotherapy by natural products: A systematic review of preclinical data and molecular mechanisms. Fitoterapia 2018, 129, 383-400. [CrossRef]

7. Kweon, S.H.; Song, J.H.; Kim, T.S. Resveratrol-mediated reversal of doxorubicin resistance in acute myeloid leukemia cells via down regulation of MRP1 expression. Biochem. Biophys. Res. Commun. 2010, 395, 104-110. [CrossRef]

8. Ko, J.C.; Syu, J.J.; Chen, J.C.; Wang, T.J.; Chang, P.Y.; Chen, C.Y.; Jian, Y.T.; Jian, Y.J.; Lin, Y.W. Resveratrol Enhances EtoposideInduced Cytotoxicity through Down-Regulating ERK1/2 and AKT-Mediated X-ray Repair Cross-Complement Group 1 (XRCC1) Protein Expression in Human Non-Small-Cell Lung Cancer Cells. Basic Clin. Pharmacol. Toxicol. 2015, 117, 383-391. [CrossRef] [PubMed]

9. Liu, D.; Yan, L.; Wang, L.; Tai, W.; Wang, W.; Yang, C. Genistein enhances the effect of cisplatin on the inhibition of non-small cell lung cancer A549 cell growth in vitro and in vivo. Oncol. Lett. 2014, 8, 2806-2810. [CrossRef] [PubMed]

10. Du, B.; Jiang, L.; Xia, Q.; Zhong, L. Synergistic inhibitory effects of curcumin and 5-fluorouracil on the growth of the human colon cancer cell line HT-29. Chemotherapy 2006, 52, 23-28. [CrossRef]

11. Montopoli, M.; Ragazzi, E.; Froldi, G.; Caparrotta, L. Cell-cycle inhibition and apoptosis induced by curcumin and cisplatin or oxaliplatin in human ovarian carcinoma cells. Cell Prolif. 2009, 42, 195-206. [CrossRef]

12. Papież, M.A.; Krzyściak, W.; Szade, K.; Bukowska-Straková, K.; Kozakowska, M.; Hajduk, K.; Bystrowska, B.; Dulak, J.; Jozkowicz, A. Curcumin enhances the cytogenotoxic effect of etoposide in leukemia cells through induction of reactive oxygen species. Drug Des. Devel. Ther. 2016, 10, 557-570. [CrossRef] [PubMed]

13. Gong, Ch.; Yang, Z.; Zhang, L.; Wang, Y.; Gong, W.; Liu, Y. Quercetin suppresses DNA double-strand break repair and enhances the radiosensitivity of human ovarian cancer cells via p53-dependent endoplasmic reticulum stress pathway. OncoTargets Ther. 2018, 11, 17-27. [CrossRef]

14. Montecucco, A.; Zanetta, F.; Biamonti, G. Molecular mechanisms of etoposide. EXCLI J. 2015, 14, 95-108. [CrossRef]

15. Sinha, B.K. Role of Oxygen and Nitrogen Radicals in the Mechanism of Anticancer Drug Cytotoxicity. J. Cancer Sci. Ther. 2020, 12, 10-18. [PubMed]

16. Wu, W.; Yang, B.; Qiao, Y.; Zhou, Q.; He, H.; He, M. Kaempferol protects mitochondria and alleviates damages against endotheliotoxicity induced by doxorubicin. Biomed. Pharmacother. 2020, 126, 110040. [CrossRef]

17. He, H.; Luo, Y.; Qiao, Y.; Zhang, Z.; Yin, D.; Yao, J.; You, J.; He, M. Curcumin attenuates doxorubicin-induced cardiotoxicity via suppressing oxidative stress and preventing mitochondrial dysfunction mediated by 14-3-3 $\gamma$. Food Funct. 2018, 9, 4404-4418. [CrossRef]

18. Chen, X.; Peng, X.; Luo, Y.; You, J.; Yin, D.; Xu, Q.; He, H.; He, M. Quercetin protects cardiomyocytes against doxorubicin-induced toxicity by suppressing oxidative stress and improving mitochondrial function via 14-3-3 $\gamma$. Toxicol. Mech. Methods 2019, 29, 344-354. [CrossRef] [PubMed]

19. Kluska, M.; Juszczak, M.; Wysokiński, D.; Żuchowski, J.; Stochmal, A.; Woźniak, K. Kaempferol derivatives isolated from Lens culinaris Medik. reduce DNA damage induced by etoposide in peripheral blood mononuclear cells. Toxicol. Res. 2019, 8, 896-907. [CrossRef]

20. Sak, K. Cytotoxicity of dietary flavonoids on different human cancer types. Pharmacogn. Rev. 2014, 8, 122-146. [CrossRef]

21. Riahi-Chebbi, I.; Souid, S.; Othman, H.; Haoues, M.; Karoui, H.; Morel, A.; Srairi-Abid, N.; Essafi, M.; Essafi-Benkhadir, K. The Phenolic compound Kaempferol overcomes 5-fluorouracil resistance in human resistant LS174 colon cancer cells. Sci. Rep. 2019, 9, 195. [CrossRef] [PubMed]

22. Wang, J.; Fang, X.; Ge, L.; Cao, F.; Zhao, L.; Wang, Z.; Xiao, W. Antitumor, antioxidant and anti-inflammatory activities of kaempferol and its corresponding glycosides and the enzymatic preparation of kaempferol. PLoS ONE 2018, 13, e0197563. [CrossRef] [PubMed]

23. Lee, H.S.; Cho, H.J.; Yu, R.; Lee, K.W.; Chun, H.S.; Park, J.H. Mechanisms underlying apoptosis-inducing effects of Kaempferol in HT-29 human colon cancer cells. Int. J. Mol. Sci. 2014, 15, 2722-2737. [CrossRef] 
24. Wu, L.Y.; Lu, H.F.; Chou, Y.C.; Shih, Y.L.; Bau, D.T.; Chen, J.C.; Hsu, S.C.; Chung, J.G. Kaempferol induces DNA damage and inhibits DNA repair associated protein expressions in human promyelocytic leukemia HL-60 cells. Am. J. Chin. Med. 2015, 43, 365-382. [CrossRef]

25. Zhu, L.; Xue, L. Kaempferol Suppresses Proliferation and Induces Cell Cycle Arrest, Apoptosis, and DNA Damage in Breast Cancer Cells. Oncol. Res. 2019, 27, 629-634. [CrossRef]

26. Goodenow, D.; Emmanuel, F.; Berman, C.; Sahyouni, M.; Richardson, C. Bioflavonoids cause DNA double-strand breaks and chromosomal translocations through topoisomerase II-dependent and -independent mechanisms. Mutat. Res. 2020, 849, 503144. [CrossRef] [PubMed]

27. Podhorecka, M.; Skladanowski, A.; Bozko, P. H2AX Phosphorylation: Its Role in DNA Damage Response and Cancer Therapy. J. Nucleic Acids 2010, 2010, 920161. [CrossRef]

28. Macieja, A.; Kopa, P.; Galia, G.; Pastwa, E.; Majsterek, I.; Popławski, T. Comparison of the effect of three different topoisomerase II inhibitors combined with cisplatin in human glioblastoma cells sensitized with double strand break repair inhibitors. Mol. Biol. Rep. 2019, 46, 3625-3636. [CrossRef] [PubMed]

29. Papież, M.; Krzyściak, W. The antioxidant quercetin protects HL-60 cells with high myeloperoxidase activity against pro-oxidative and apoptotic effects of etoposide. Acta Biochem. Pol. 2014, 61, 795-799. [CrossRef]

30. Li, N.; Sun, Ch.; Zhou, B.; Xing, H.; Ma, D.; Chen, G.; Weng, D. Low Concentration of Quercetin Antagonizes the Cytotoxic Effects of Anti-Neoplastic Drugs in Ovarian Cancer. PLoS ONE 2014, 9, e100314. [CrossRef]

31. Moradzadeh, M.; Tabarraei, A.; Sadeghnia, H.R.; Ghorbani, A.; Mohamadkhani, A.; Erfanian, S.; Sahebkar, A. Kaempferol increases apoptosis in human acute promyelocytic leukemia cells and inhibits multidrug resistance genes. J. Cell Biochem. 2018, 119, 2288-2297. [CrossRef] [PubMed]

32. Guo, H.; Ren, F.; Zhang, L.; Zhang, X.; Yang, R.; Xie, B.; Li, Z.; Hu, Z.; Duan, Z.; Zhang, J. Kaempferol induces apoptosis in HepG2 cells via activation of the endoplasmic reticulum stress pathway. Mol. Med. Rep. 2016, 13, 2791-2800. [CrossRef]

33. Kashafi, E.; Moradzadeh, M.; Mohamadkhani, A.; Erfanian, S. Kaempferol increases apoptosis in human cervical cancer HeLa cells via PI3K/AKT and telomerase pathways. Biomed. Pharmacother. 2017, 89, 573-577. [CrossRef] [PubMed]

34. Kumar, A.D.; Bevara, G.B.; Kaja, L.K.; Badana, A.K.; Malla, R.R. Protective effect of 3-O-methyl quercetin and kaempferol from Semecarpus anacardium against $\mathrm{H}_{2} \mathrm{O}_{2}$ induced cytotoxicity in lung and liver cells. BMC Complement. Altern. Med. 2016, 16, 376. [CrossRef] [PubMed]

35. Nandi, D.; Besra, S.E.; Vedasiromoni, J.R.; Giri, V.S.; Rana, P.; Jaisankar, P. Anti-leukemic activity of Wattakaka volubilis leaf extract against human myeloid leukemia cell lines. J. Ethnopharmacol. 2012, 144, 466-473. [CrossRef] [PubMed]

36. Żuryń, A.; Krajewski, A.; Szulc, D.; Litwiniec, A.; Grzanka, A. Activity of cyclin B1 in HL-60 cells treated with etoposide. Acta Histochem. 2016, 118, 537-543. [CrossRef] [PubMed]

37. Moskot, M.; Jakóbkiewicz-Banecka, J.; Smolińska, E.; Piotrowska, E.; Węgrzyn, G.; Gabig-Cimińska, M. Effects of flavonoids on expression of genes involved in cell cycle regulation and DNA replication in human fibroblasts. Mol. Cell Biochem. 2015, 407, 97-109. [CrossRef]

38. Gao, Y.; Yin, J.; Rankin, G.O.; Chen, Y.C. Kaempferol Induces G2/M Cell Cycle Arrest via Checkpoint Kinase 2 and Promotes Apoptosis via Death Receptors in Human Ovarian Carcinoma A2780/CP70 Cells. Molecules 2018, 23, 1095. [CrossRef] [PubMed]

39. Kim, K.Y.; Jang, W.Y.; Lee, J.Y.; Jun do, Y.; Ko, J.Y.; Yun, Y.H.; Kim, Y.H. Kaempferol Activates G2-Checkpoint of the Cell Cycle Resulting in G2-Arrest and Mitochondria-Dependent Apoptosis in Human Acute Leukemia Jurkat T Cells. J. Microbiol. Biotechnol. 2016, 26, 287-294. [CrossRef]

40. Jain, C.K.; Majumder, H.K.; Roychoudhury, S. Natural Compounds as Anticancer Agents Targeting DNA Topoisomerases. Curr. Genom. 2017, 18, 75-92. [CrossRef]

41. Saleh, E.M.; El-Awady, R.A.; Eissa, N.A.; Abdel-Rahman, W.M. Antagonism between curcumin and the topoisomerase II inhibitor etoposide: A study of DNA damage, cell cycle regulation and death pathways. Cancer Biol. Ther. 2012, 13, 1058-1071. [CrossRef]

42. Mahbub, A.A.; Le Maitre, C.L.; Haywood-Small, S.L.; Cross, N.A.; Jordan-Mahy, N. Glutathione is key to the synergistic enhancement of doxorubicin and etoposide by polyphenols in leukaemia cell lines. Cell Death Dis. 2015, 6, e2028. [CrossRef] [PubMed]

43. Żuchowski, J.; Pecio, Ł.; Stochmal, A. Novel flavonol glycosides from the aerial parts of lentil (Lens culinaris). Molecules 2014, 19, 18152-18178. [CrossRef]

44. Juszczak, M.; Kluska, M.; Wysokiński, D.; Woźniak, K. DNA damage and antioxidant properties of CORM-2 in normal and cancer cells. Sci. Rep. 2020, 10, 12200. [CrossRef]

45. Singh, N.P.; McCoy, T.; Tice, R.R.; Schneider, E.L. A simple technique for quantitation of low levels of DNA damage in individual cells. Exp. Cell Res. 1988, 175, 184-192. [CrossRef] 